\title{
Inequalities in access to hospitals: a case study in the Islamic Republic of Iran 1997-2012
}

Sohyla Reshadat, ${ }^{1}$ Alireza Zangeneh, ${ }^{1}$ Shahram Saeidi, ${ }^{1}$ SeyedRamin Ghasemi, ${ }^{1}$ Nader Rajabi-Gilan ${ }^{2}$ and Ali Zakiei ${ }^{2}$

${ }^{1}$ Social Development and Health Promotion Research Center, Kermanshah University of Medical Sciences, Kermanshah, Islamic Republic of Iran. (Correspondence to: Alireza Zangeheh: ali.zangeneh88@gmail.com). ${ }^{2}$ Sleep Disorders Research Center, Kermanshah University of Medical Sciences, Kermanshah, Islamic Republic of Iran.

\begin{abstract}
Background: Nowadays, the significance of applying Geographic information system (GIS) to survey accessibility to hospitals and understanding disparities in this regard has increased.

Aims: The main aim of this descriptive-analytical research was to study the spatial accessibility of the population of Kermanshah for 3 years 1997 ( $n=693157), 2007(n=794863)$, and 2012 ( $n=851$ 405) to hospitals based on age and gender groups through GIS.

Methods: The study was conducted based on network analysis models, mean centre, and standard distance in the environment of Arc/GIS. A standard radius of 1500 metres was set for the medical centres, and a 25-minute walking span was set for the distance of each person from home to the nearest hospital.

Results: The results of the network analysis demonstrated that the hospitals were inaccessible to the populations according to our criteria, and their geographical access to hospitals measured $68.80 \%, 64.23 \%$ and $66.20 \%$ in 1997,2007 , and 2012 , respectively. Women aged 65 years and above were more at risk in this regard.
\end{abstract}

Conclusions: Over the total period under study, the results revealed that hospitals were concentrated in the central and southern areas of Kermanshah.

Keywords: Society, geographical access, health management, GIS, hospitals.

Citation: Reshadat S; Zangeneh A; Saeidi S; Ghasemi S R; Rajabi-Gilan N; Zakiei A. Inequalities in access to hospitals: a case study in the Islamic Republic of Iran 1997-2012. East Mediterr Health J. 2019;25(2):119-126. https://doi.org/10.26719/emhj.18.061

Received: 25/10/15; accepted: 25/10/17

Copyright (c) World Health Organization (WHO) 2019. Some rights reserved. This work is available under the CC BY-NC-SA 3.o IGO license (https:// creativecommons.org/licenses/by-nc-sa/3.o/igo).

\section{Introduction}

Equitable access to health services results supports social welfare as well as economic growth and social development (1). Equitable access is a major concern for healthcare managers who argue that mismanagement of the issue has repercussions for mortality and morbidity globally $(2-5)$. Access is defined as the relative ease to reach a given location (6) based on two criteria: availability of services and access to services (7). In this regard, studies have indicated that distance and time are both seen as two crucial factors in access to healthcare services $(8,9)$. To understand access to healthcare services and their appropriate spatial distribution are important for policymakers and stakeholders from two perspectives: changes in demand and supply, and cost minimization (10).

Today, geographic information systems (GIS) are much in demand and are employed as a tool to facilitate vulnerable and deprived communities' access to hospitals (11), palliative care (12), and primary healthcare needs (13). Hence, given the growing urban population, the demand for healthcare services is increasing and GIS can be employed for better management and thus better access to healthcare services (14). Although urbanization in the Islamic Republic of Iran has witnessed enormous growth over the past four decades, many areas are still medically underserved (15) and Kermanshah is no exception to the rule (15-17).

The Islamic Republic of Iran contains 31 provinces; Kermanshah Province, with an area of approximately 10000 hectares, is located in the west of the country (18). The population in 2012 was 851405 and served by 13 hospitals. A city is a densely populated area with political, administrative and historical centralization whose residents are primarily involved in nonagricultural occupations. However, a conurbation enjoys a special economic-political centralization that has a central position at regional or national levels and is simultaneously in the first place in terms of controlling its surrounding region economically (19). In this regard, Kermanshah was a city according to Iranian national classifications in 2011 and was then described as a conurbation as the city developed. Given the prominence of geographical access to hospitals, lack of geographical access to such services and the background of this issue in Kermanshah, the present study aimed to investigate the spatial access to hospitals through GIS from 1997 to 2012 in the conurbation of Kermanshah, Islamic Republic of Iran.

\section{Methods}

\section{Study setting and data sources}

Data were extracted from the statistical database on 
population clusters in Kermanshah for three years (1997, 2007 and 2012), which were based on the population and household census in Kermanshah and compiled by the Statistical Center, Tehran. Hospital information was sourced from the Health Promotion Research Center, Kermanshah University of Medical Sciences. The urban road networks and hospitals based in the region were statistically studied and the topology and spatial relations between the road networks were re-created as map documents using ArcCatalog (Esri, New York, NY, USA), and environmental restrictions applied through Network Analysis. The population of Kermanshah was calculated to be 693 157, 794863 and 851405 in 1997, 2007, and 2012, respectively, and was served by 10, 14 and 13 hospitals, respectively.

\section{Study models}

This descriptive and analytical research was based on network analysis, mean centre and standard distance models using Arc/GIS 9.3. The models in our research are as follows:

A) Mean centre: Calculated as the mean of geographical latitude and longitude coordinates of all features within the scope of the study using the following equation (20):

Equation (1): $=\bar{X}=\sum_{i=1}^{n} \frac{\mathrm{Xi}}{n} \bar{Y}=\sum_{i=1}^{n} \frac{\mathrm{Yi}}{n}$

Where Xi and Yi represent the coordinates of the areas of $i$ and $n$ is equal to the total number of features and areas.

B) Standard distance (SD): A method for examining the level of concentration or dispersion of geographic features around the mean centre and is calculated as following equation (20):

Equation (2): $\mathrm{SD}=\sqrt{\sum^{\mathrm{Di}} / \mathrm{n}}$

Where $\mathrm{Di}$ is the distance between two points, the mean centre, and n points.

\section{Data collection}

In the current study, the appropriate and actual geographical access to hospitals was assessed. Appropriate access denotes access to hospital services based on the standard used in the study, while actual access denotes the residents' current access ability. Geographical access has been traditionally measured by the distance or (travel time) to the nearest facility. However, geographical access as a measure does not take into account all access variables faced by communities. The GIS platform helps to address most of these problems within the standard radius, and GIS network analysis serves as an advanced method in this regard.

Networks used by Arc/GIS Network Analyst are stored as network datasets. A network dataset is created from the feature source or sources that participate in the network. It incorporates an advanced connectivity model that can represent complex scenarios, such as multimodal transportation networks. It also possesses a rich network attribute model that helps model impedances, restrictions, and hierarchy for the network. The network dataset is built from simple features (lines and points) and turns. This network has a streets feature class that can act as an edge source, a street intersections feature class acting as a junction source, additional line feature classes that act as edges (streets), and point feature classes that act as junctions (hospitals).

The urban movement practices include walking and using vehicles (21). The movement practices and geographic access to healthcare services and hospitals are often calculated using the estimation of travel time through GIS (22). In the present study, the walking span was considered according to the standard accessibility radius of $1500 \mathrm{~m}$ for hospitals $(15,19)$ and taking the velocity of a person's movement while walking to be between 0.75 and $1.25 \mathrm{~m} / \mathrm{s}$ (average $1 \mathrm{~m} / \mathrm{s}$ ) (23); a walking duration of 25 minutes for each individual from home to the nearest hospital was set in this research. Using the scores of the extension in Network Analysis, some borders were created in the regions where hospitals were supplied. The layers of the statistical blocks containing the demographic data (sex and age) were separated from the original map of the city using intersect and symmetrical difference, thereby the populations in geographical access were assessed based on sex (male and female) and three age groups (0-14, 15-64 and > 65 years) (24).

To identify the areas with and without geographical access, the following instruments were exploited:

A) Intersect: The geometric intersection of the input features is computed. The features or portions of features that overlap in all layers and/or feature classes are exported to the output feature class (25).

B) Symmetrical difference: The geometric intersection of the input and updated features is computed. The features or portions of features in the input and updated features that do not overlap are exported to the output feature class (25).

\section{Results}

Figure 1 shows the accessibility status of the target community to the hospitals settled in Kermanshah in 1997, 2007 and 2012. The results demonstrated that despite the increasing number of hospitals from 10 to 13 from 1997 to 2012, the percentage of the population with geographical access to hospitals decreased (Figure 1), and therefore was considered a demonstration of inequity in access to hospitals. The results also revealed that the hospitals were inaccessible to populations according to our criteria, and the percentage of the population without geographical access rose $(68.80 \%, 64.23 \%$ and $66.20 \%$ in 1997,2007 and 2012, respectively) (Table 1).

For the 0-14 age group, 39.11\% did not have any geographical access to hospitals in 1997 according to our criteria, which dropped to $23.54 \%$ in 2007 and $20.56 \%$ in 2012. For the 15-64 age group, the percentage without geographical access to hospitals according to our criteria was $56.19 \%$ in 1997 , rising to $71.08 \%$ in 2007 and $74.60 \%$ in 2012. For the age group 65 years and above, $4.70 \%$ did 

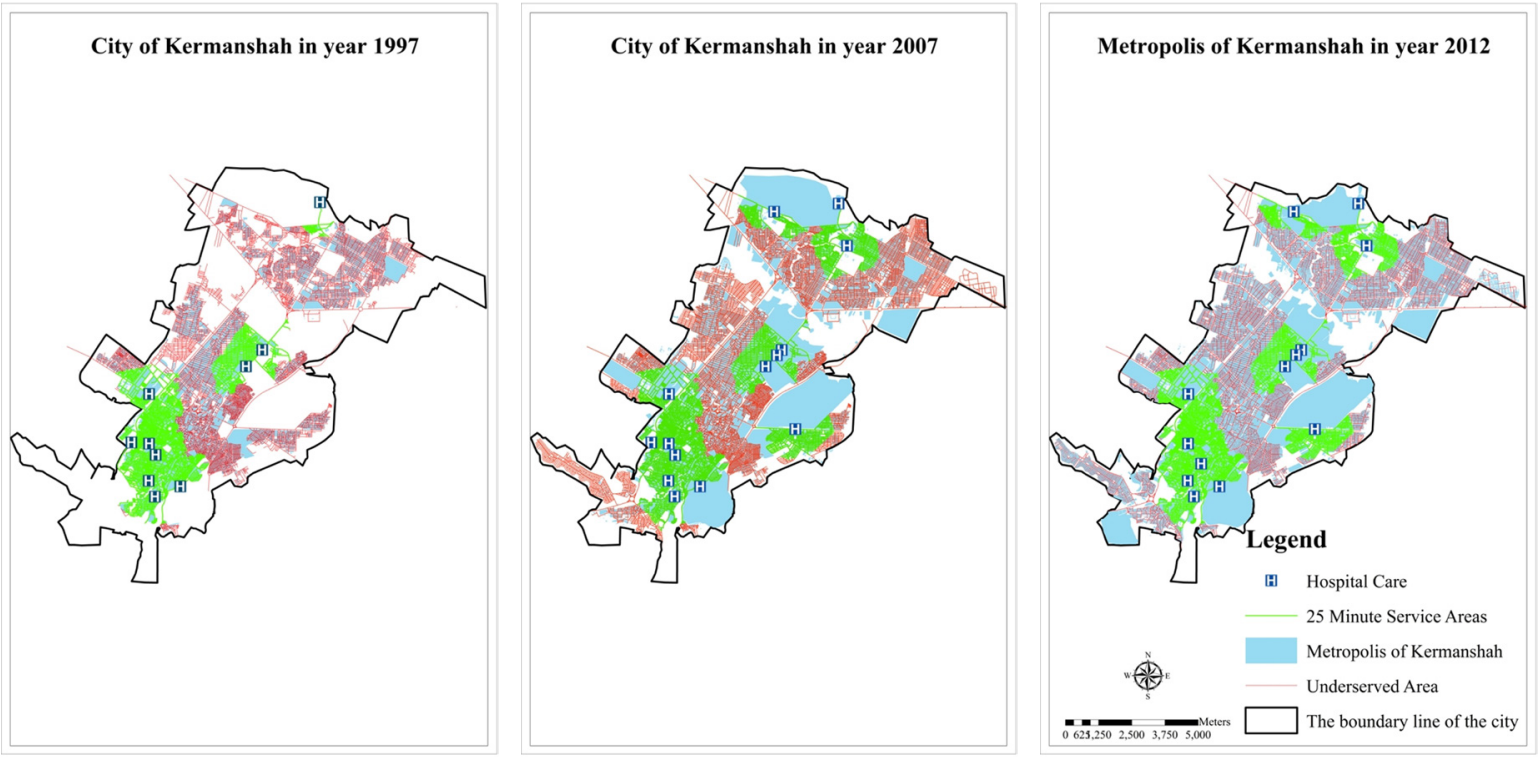

Figure 1 The spatial distribution of Hospitals and areas within or outside their coverage in the Kermanshah in 1997, 2007-2012

not have any geographical access to hospitals in 1997 according to our criteria, rising to $5.38 \%$ in 2007 , but falling to $4.84 \%$ in 2012 (Table 1 and Figure 2).

The results revealed that the mean centre of all hospitals overlapped with the geographical centre of the city during the mentioned periods of study, indicating inequity in access to hospitals according to our second criteria in this regard. However, the mean centre was affected by two hospitals established in the northern area of the city in 2007. Additionally, the mean centre was affected by the establishment of hospitals in the southern area of the city in 2012. Furthermore, based

\begin{tabular}{|c|c|c|c|c|c|c|c|c|c|c|}
\hline \multirow{2}{*}{$\begin{array}{l}\text { Year } \\
\text { Access }\end{array}$} & \multirow[b]{2}{*}{$\begin{array}{l}\text { Age } \\
\text { Group }\end{array}$} & \multicolumn{3}{|c|}{1997} & \multicolumn{3}{|c|}{2007} & \multicolumn{3}{|c|}{2012} \\
\hline & & $\begin{array}{l}\text { Female } \\
\text { No. (\%) }\end{array}$ & $\begin{array}{c}\text { Male } \\
\text { No. (\%) }\end{array}$ & $\begin{array}{c}\text { Both } \\
\text { Sexes } \\
\text { No. (\%) }\end{array}$ & $\begin{array}{l}\text { Female } \\
\text { No. (\%) }\end{array}$ & $\begin{array}{c}\text { Male } \\
\text { No. (\%) }\end{array}$ & $\begin{array}{l}\text { Both } \\
\text { Sexes } \\
\text { No. (\%) }\end{array}$ & $\begin{array}{l}\text { Female } \\
\text { No. (\%) }\end{array}$ & $\begin{array}{c}\text { Male } \\
\text { No. (\%) }\end{array}$ & $\begin{array}{c}\text { Both } \\
\text { Sexes } \\
\text { No. (\%) }\end{array}$ \\
\hline \multirow[t]{4}{*}{ Without Access } & $0-14$ & $\begin{array}{c}85666 \\
(38.88)\end{array}$ & $\begin{array}{l}89997 \\
(39.32)\end{array}$ & $\begin{array}{c}175663 \\
(39.11)\end{array}$ & $\begin{array}{l}57528 \\
(23.14)\end{array}$ & $\begin{array}{l}62692 \\
(23.93)\end{array}$ & $\begin{array}{l}120220 \\
(23.54)\end{array}$ & $\begin{array}{c}55861 \\
(19.85)\end{array}$ & $\begin{array}{l}60034 \\
(21.26)\end{array}$ & $\begin{array}{l}115895 \\
(20.56)\end{array}$ \\
\hline & $15-64$ & $\begin{array}{l}125153 \\
(56.81)\end{array}$ & $\begin{array}{l}127238 \\
(55.59)\end{array}$ & $\begin{array}{l}252391 \\
(56.19)\end{array}$ & $\begin{array}{r}178647 \\
(71.86)\end{array}$ & $\begin{array}{l}184230 \\
(70.33)\end{array}$ & $\begin{array}{c}362877 \\
(71.07)\end{array}$ & $\begin{array}{l}211828 \\
(75.26)\end{array}$ & $\begin{array}{c}208690 \\
(73.94)\end{array}$ & $\begin{array}{l}420518 \\
(74.60)\end{array}$ \\
\hline & $>65$ & $\begin{array}{l}9497 \\
(4.31)\end{array}$ & $\begin{array}{l}11645 \\
(5.09)\end{array}$ & $\begin{array}{l}21142 \\
(4.70)\end{array}$ & $\begin{array}{c}12416 \\
\text { (5) }\end{array}$ & $\begin{array}{l}15053 \\
(5.74)\end{array}$ & $\begin{array}{l}27469 \\
(5.38)\end{array}$ & $\begin{array}{l}13771 \\
(4.89)\end{array}$ & $\begin{array}{l}13529 \\
(4.80)\end{array}$ & $\begin{array}{l}27300 \\
(4.84)\end{array}$ \\
\hline & total & $\begin{array}{c}220316 \\
(100)\end{array}$ & $\begin{array}{c}228880 \\
(100)\end{array}$ & $\begin{array}{c}449196 \\
(100)\end{array}$ & $\begin{array}{c}248591 \\
(100)\end{array}$ & $\begin{array}{c}261975 \\
(100)\end{array}$ & $\begin{array}{c}510566 \\
(100)\end{array}$ & $\begin{array}{c}281460 \\
(100)\end{array}$ & $\begin{array}{c}282253 \\
(100)\end{array}$ & $\begin{array}{c}563713 \\
(100)\end{array}$ \\
\hline \multirow[t]{4}{*}{$\begin{array}{l}\text { Total } \\
\text { population }\end{array}$} & $0-14$ & $\begin{array}{l}129812 \\
(38.14)\end{array}$ & $\begin{array}{l}136221 \\
(38.61)\end{array}$ & $\begin{array}{r}266033 \\
(38.38)\end{array}$ & $\begin{array}{c}87483 \\
(22.48)\end{array}$ & $\begin{array}{l}94537 \\
(23.31)\end{array}$ & $\begin{array}{l}182020 \\
(22.90)\end{array}$ & $\begin{array}{l}82930 \\
(19.43)\end{array}$ & $\begin{array}{c}88355 \\
(20.81)\end{array}$ & $\begin{array}{l}171285 \\
(20.11)\end{array}$ \\
\hline & $15-64$ & $\begin{array}{l}192633 \\
(56.61)\end{array}$ & $\begin{array}{l}195413 \\
(55.39)\end{array}$ & $\begin{array}{c}388046 \\
(55.99)\end{array}$ & $\begin{array}{c}280484 \\
(72.04)\end{array}$ & $\begin{array}{c}285804 \\
(70.47)\end{array}$ & $\begin{array}{c}566288 \\
(71.24)\end{array}$ & $\begin{array}{l}318632 \\
(74.66)\end{array}$ & $\begin{array}{l}311910 \\
(73.46)\end{array}$ & $\begin{array}{l}630542 \\
(74.06)\end{array}$ \\
\hline & $>65$ & $\begin{array}{l}17879 \\
(5.25)\end{array}$ & $\begin{array}{c}21199 \\
(6)\end{array}$ & $\begin{array}{c}39078 \\
(5.63)\end{array}$ & $\begin{array}{l}21336 \\
(5.48)\end{array}$ & $\begin{array}{l}25219 \\
(6.22)\end{array}$ & $\begin{array}{l}46554 \\
(5.86)\end{array}$ & $\begin{array}{l}25211 \\
(5.91)\end{array}$ & $\begin{array}{r}24367 \\
(5.73)\end{array}$ & $\begin{array}{c}49578 \\
(5.83)\end{array}$ \\
\hline & total & $\begin{array}{c}340324 \\
(100)\end{array}$ & $\begin{array}{c}352833 \\
(100)\end{array}$ & $\begin{array}{c}693157 \\
(100)\end{array}$ & $\begin{array}{c}389303 \\
(100)\end{array}$ & $\begin{array}{c}405560 \\
(100)\end{array}$ & $\begin{array}{c}794862 \\
(100)\end{array}$ & $\begin{array}{c}426773 \\
(100)\end{array}$ & $\begin{array}{c}424632 \\
(100)\end{array}$ & $\begin{array}{c}851405 \\
(100)\end{array}$ \\
\hline \multirow{4}{*}{$\begin{array}{l}\text { Proportion of } \\
\text { age groups } \\
\text { to the whole } \\
\text { population }\end{array}$} & $0-14$ & 18.73 & 19.65 & 38.38 & 11.01 & 11.89 & 22.90 & 9.74 & 10.38 & 20.11 \\
\hline & $15-64$ & 27.79 & 28.19 & 55.99 & 35.29 & 35.96 & 71.24 & 37.42 & 36.63 & 74.06 \\
\hline & $>65$ & 2.58 & 3.06 & 5.64 & 2.68 & 3.17 & 5.86 & 2.96 & 2.86 & 5.83 \\
\hline & total & 49.10 & 50.90 & 100 & 48.98 & 51.02 & 100 & 50.13 & 49.87 & 100 \\
\hline \multirow{4}{*}{$\begin{array}{l}\text { Proportion of } \\
\text { population } \\
\text { without access } \\
\text { to the whole } \\
\text { population }\end{array}$} & $0-14$ & 12.36 & 12.98 & 25.34 & 7.23 & 7.89 & 15.12 & 6.56 & 7.05 & 13.61 \\
\hline & $15-64$ & 18.05 & 18.36 & 36.41 & 22.48 & 23.18 & 45.65 & 24.88 & 24.51 & 49.39 \\
\hline & $>65$ & 1.37 & 1.68 & 3.05 & 1.56 & 1.89 & 3.45 & 1.62 & 1.59 & 3.21 \\
\hline & total & 31.78 & 33.02 & 64.80 & 31.27 & 32.96 & 64.23 & 33.06 & 33.15 & 66.21 \\
\hline
\end{tabular}




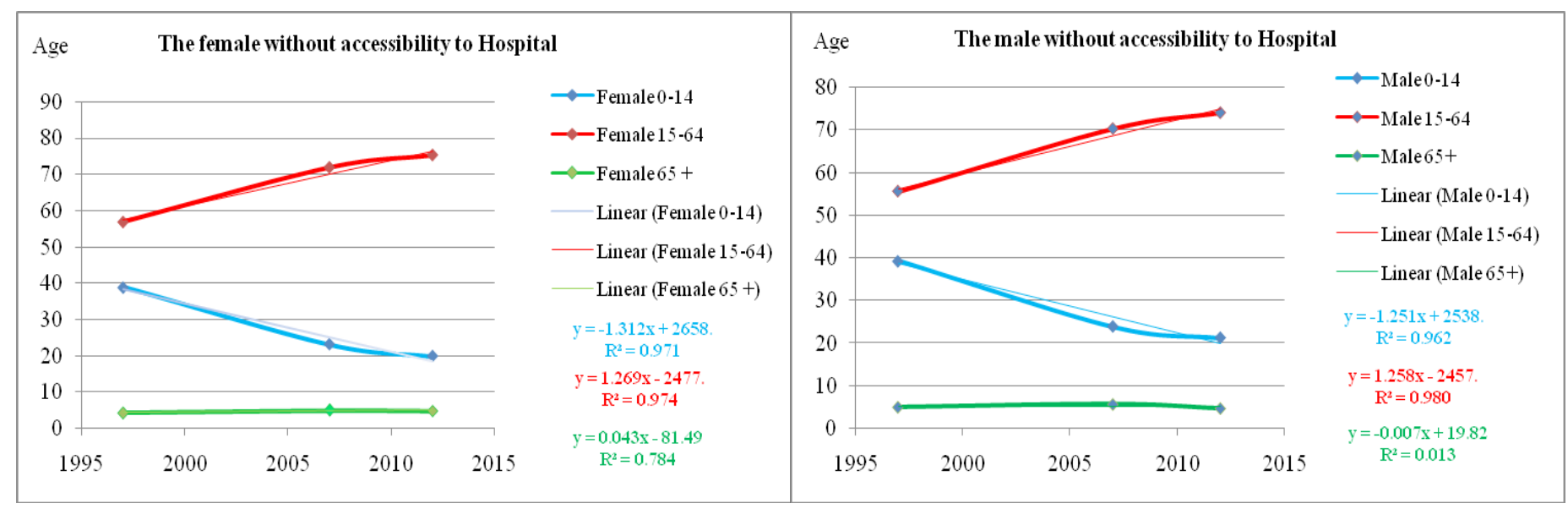

Figure 2 Population deprived of access to hospitals in terms of gender and age groups in Kermanshah in 1997, 2007-2012

on the standard distance, the results revealed that most of the hospitals were concentrated in the central and southern parts of Kermanshah conurbation, and there was a cumulative distribution of hospitals in these areas (Figure 3). Our data in this regard revealed inequity in access to hospitals according to our third criteria in this regard.

\section{Discussion}

The present study indicated that geographical access of the target population to hospitals held a downward trend during the total study period. In this regard, several factors might have contributed to this trend, including: 1) the growing rate of population (Table 1), 2) the inappropriate

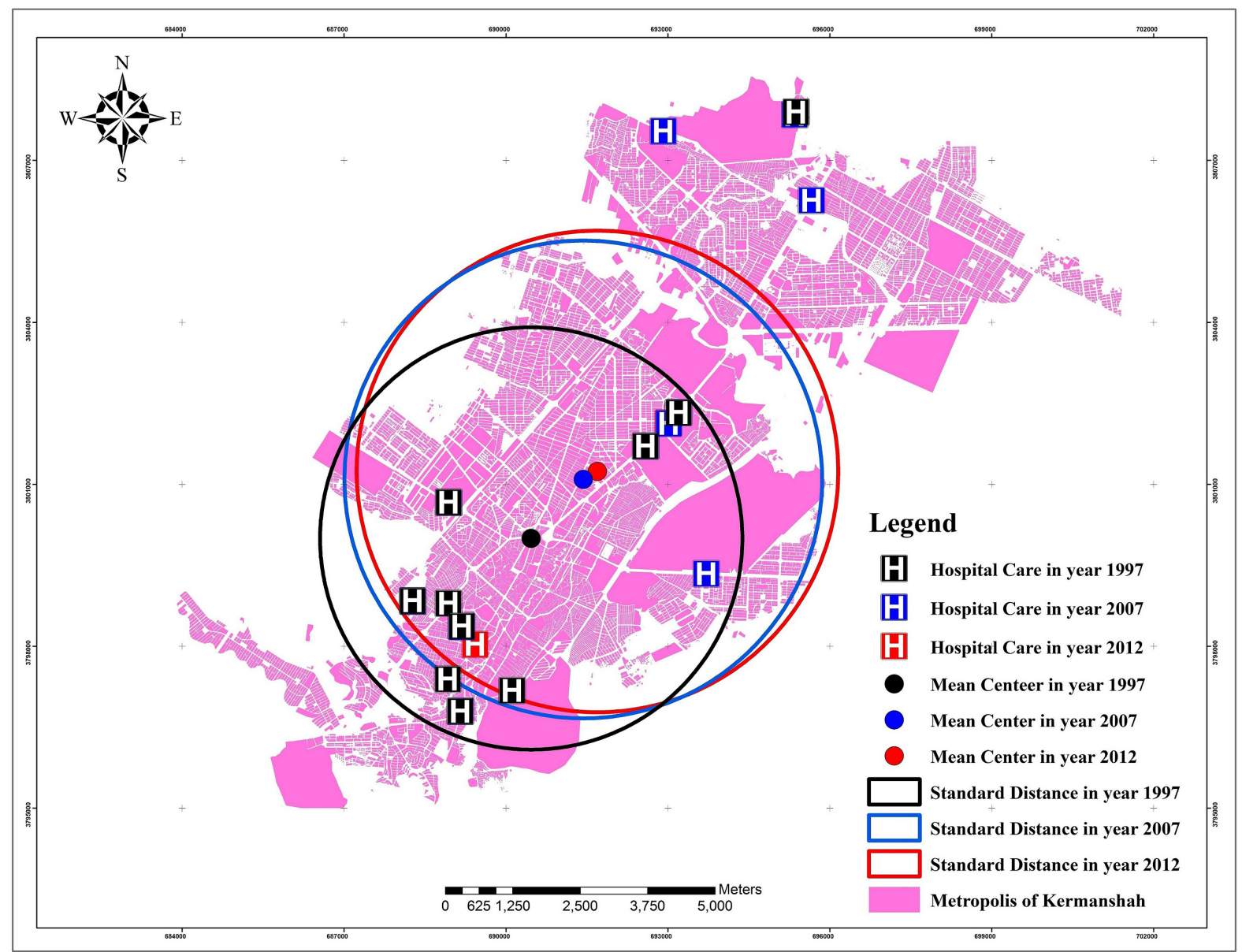

Figure 3 Mean centre and standard distance of hospitals in Kermanshah in 1997, 2007-2012 
spatial distribution of hospitals across the city, as shown in the present research and other Iranian studies $(15,16)$; and 3) migration of people from central city areas to outlying zones due to various reasons including poor quality housing, inefficient transport networks, lack of proper urban facilities, and re-designation of settlements as commercial and/or administrative, but still fall under the coverage of hospitals in Kermanshah (26). Moreover, the newly established hospitals did improve the inhabitants' geographical access over the period of study.

Lack of geographical access to such services has been observed in similar studies such as the one conducted in Alabama and Kentucky, United States of America (27), which revealed that a $22.9 \%$ drop in mortality rates was a direct result of improved availability and accessibility to healthcare services. In addition, the study pointed out that mortality rates were not only a result of demographic characteristics (28), but inequity might have also affected the epidemic patterns of disorders and might have resulted in unexpected events (29). The issue of appropriate geographical access to hospitals and healthcare centers is not surprising, and it is regarded as a national goal in some countries $(28,30)$. Therefore, it is suggested that the healthcare managers of Kermanshah apply such policies towards creating appropriate geographical access to hospitals.

The geographical access of the 0-14 age group to hospitals during the period under study showed that hospitals were inaccessible according to our criteria and held a downward trend (Table 1 and Figure 2). A possible reason for this might be changes in the fertility rates in Kermanshah, thereby influencing the downward trend. Likewise, studies conducted in Kermanshah suggested that the total fertility rate declined from 2.50 in 1997 to 1.72 in 2012 (31), thereby reducing this age group and affecting the results of the present study.

Inequalities in geographical access to healthcare services, i.e. hospitals, especially with regard to children, could have adverse repercussions, including growing mortality rates and outpatient referrals. In a study performed by Wang (2012), he concluded that the number of visits to clinics reduced by $34 \%$ per kilometre of rise in the distance of inhabitants from the medical centres through applying the variable of the nearest clinic to each child (6).

The age group of $>65$ years experienced an upward trend of non-accessibility from $4.70 \%$ in 1997 to $5.38 \%$ in 2007, yet witnessed a downward trend from 5.38\% in 2007 to $4.84 \%$ in 2012 (Table 1 and Figure 2). Possible explanations for this include: 1) reducing age group population; 2) migration of young and middle-age groups city centre areas where most hospitals are located, to areas without access according to our criteria (32); and 3) geographical access to healthcare services is a high priority for the elderly population of the target community; the results of studies performed in the United States and Spain demonstrated that the elderly population had a tendency to live in the immediate vicinity of medical facilities (27,33). Furthermore, in another study it was shown that long travel intervals between the place of residence for the elderly and medical centres created substantial physical obstacles for them (34).

Our results revealed that the elderly population without geographical access to hospitals held an upward trend, possibly ensuing from a rise in this demographic (Table 1 and Figure 2) since, according to statistical data, Kermanshah has recently attracted rural migrants from other western provinces of the country, such as Ilam and Kurdistan (26,35).

According to our data, women had greater inaccessibility to hospitals according to our criteria (Table 1 and Figure 2). The results of studies performed in the United States also demonstrated that women had the least access to medical centres (36), which was concurrent with the results of a study conducted by Buor (2003) (8). The appropriate standard of health management is of particular importance for this group, especially those at a reproductive stage in life, which has generational repercussions.

\section{Limitations}

One of the limitations of the present study was the utilization of health services, i.e. hospitals, being affected by personal characteristics, such as age, social class, economic status, transportation opportunities, etc., which were all excluded from the present study. Moreover, geographical access is also affected by other determinants such as traffic density, weather conditions and time constraints. Accordingly, it is recommended that these factors be considered in future studies.

\section{Conclusion}

According to the results of the present study, there were inequities in geographical access to hospitals in Kermanshah. The results also demonstrated that a large number of people were medically underserved, thereby holding an upward trend in this regard. Female and elderly groups were more at risk, especially females in the 15-64 age group that witnessed an upward trend, and was not resolved by newly established hospitals, as well as the fact that the majority of hospitals were concentrated in the central and southern parts of Kermanshah conurbation. GIS is a useful tool for evaluating inequality in geographical access to hospitals and can be utilized to address problems in planning and policy-making regarding the proper distribution of medical facilities. Our data showed that hospitals were not distributed in proportion to the population distribution. Consequently, it is recommended that more attention be paid to this issue by healthcare managers and GIS be employed towards establishing new hospitals appropriately in the future.

Funding: None.

Competing interests: None declared. 


\section{Inégalités en matière d'accès aux hôpitaux : étude de cas en République islamique d'Iran 1997-2012}

\section{Résumé}

Contexte : De nos jours, il devient de plus en plus important d'appliquer le système d'information géographique (GIS) aux études d'accessibilité aux hôpitaux et de comprendre les disparités associées.

Objectifs : La présente étude analytique et descriptive avait pour objectif principal d'examiner, au cours de trois années différentes (1997 [ $=693157]$; 2007 [ $=794863]$ et 2012 [ $=851405])$, l'accessibilité spatiale de la population de Kermanshah aux hôpitaux, sur la base de groupes d'âge et de sexe et au moyen du système (GIS).

Méthodes : L'étude a été menée en utilisant des modèles d'analyse du réseau et des méthodes de mesure des distances moyenne et standard jusqu'aux centres, à l'aide du logiciel d'information géographique ArcGIS. Un rayon standard de 1500 mètres a été déterminé autour des centres médicaux, de même qu'une distance de 25 minutes entre le domicile de chaque individu et l'hôpital le plus proche.

Résultats : Les résultats de l'analyse du réseau ont montré que les hôpitaux étaient inaccessibles pour la population, selon les critères que nous avions définis, et que l'accès géographique des personnes aux hôpitaux était de 68,80\%,64,23\% et $66,20 \%$ en 1997, 2007 et 2012 respectivement. Les femmes âgées de 65 ans et plus étaient sujettes à un risque plus important à cet égard.

Conclusions : Sur la période couverte par l'étude, les résultats ont révélé que les hôpitaux étaient concentrés dans les zones situées dans le centre et le sud de la ville de Kermanshah.

$$
\begin{aligned}
& \text { أوجه عدم المساواة في الوصول إلى المستشفيات: دراسة حالة في جمهورية إيران الإسلامية للفترة ما بين }
\end{aligned}
$$

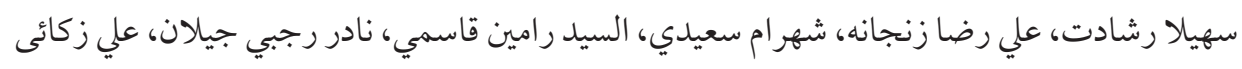

$$
\begin{aligned}
& \text { الخلاصة } \\
& \text { الخلفية: تتز ايد حاليًا أهمية تطبيق نظام المعلومات الجغر افية لاستطلاع إمكانية الوصول إلى المستشفيات وفهم التفاوت بهذا الصدد. }
\end{aligned}
$$

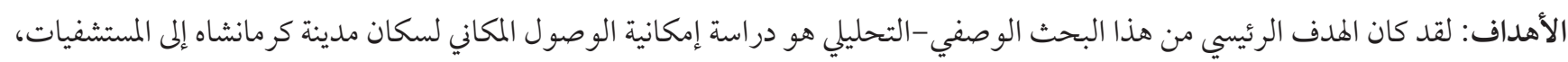

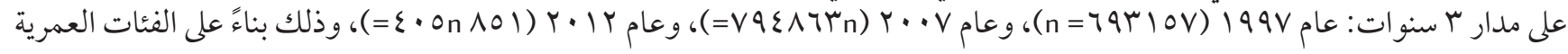

$$
\begin{aligned}
& \text { و النوع، وباستخدام نظام المعلومات الجنات الجغراف افية. }
\end{aligned}
$$

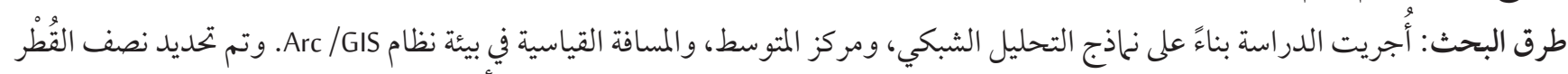

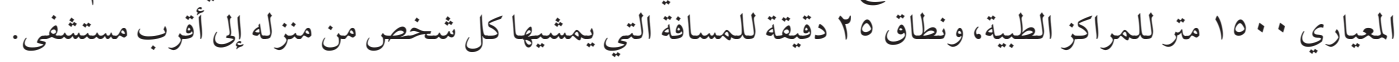

$$
\begin{aligned}
& \text { الاستناجات: على مدار المدة قيد الدراسة، أوضحت النتائج أن المستشفيات متركزة في المناطق المركزية والجنوبية في مدينة كرمانشاه. }
\end{aligned}
$$

\section{References}

1. Gulliford M, Myfanwy M. Access to health care. London, New York, NY: Routledge; 2013. http://dx.doi.org/10.4324/9780203867952

2. Zangeneh A, Najafi F, Karimi S, Saeidi S, Izadi N. Spatial-temporal cluster analysis of mortality from road traffic injuries using geographic information systems in West of Iran during 2009-2014. J Forensic Leg Med. 2018; 1(55):15-22. https://doi.org/10.1016/j. jflm.2018.02.009

3. Mestre AM, Oliveira MD, Barbosa-Póvoa AP. Location-allocation approaches for hospital network planning under uncertainty. Eur J Oper Res. 2015; 240(3):791-806. http://dx.doi.org/10.1016/j.ejor.2014.07.024

4. Clark RA, Coffee N, Turner D, Eckert KA, van Gaans D, Wilkinson D, et al. Application of geographic modeling techniques to quantify spatial access to health services before and after an acute cardiac event. The Cardiac Accessibility and Remoteness Index for Australia (ARIA) Project. Circulation. 2012; 125(16): 2006-14. http://dx.doi.org/10.1161/CIRCULATIONAHA.111.083394

5. Dudas K, Lappas G, Stewart S, Rosengren A. Trends in out-of-hospital deaths due to coronary heart disease in Sweden (1991 to 2006). Circulation. 2011; 123(1):46-52. http://dx.doi.org/10.1161/CIRCULATIONAHA.110.964999

6. Wang F. Measurement, optimization, and impact of health care accessibility: a methodological review. Ann Assoc Am Geogr. 2012; 102(5):1104-12. http://dx.doi.org/10.1080/00045608.2012.657146 
7. Delamater PL. Spatial accessibility in suboptimally configured health care systems: A modified two-step floating catchment area (M2SFCA) metric. Health Place. 2013; 1(24): 30-43. http://dx.doi.org/10.1016/j.healthplace.2013.07.012

8. Buor D. Analysing the primacy of distance in the utilization of health services in the Ahafo-Ano South district, Ghana. Int J Health Plann Manage. 2003; 18(4): 293-311. http://dx.doi.org/10.1002/hpm.729

9. Hu R, Dong S, Zhao Y, Hu H, Li Z. Assessing potential spatial accessibility of health services in rural China: a case study of Donghai county. Int J Equity Health. 2013; 12(1): 1-11. http://dx.doi.org/10.1186/1475-9276-12-35

10. Yao J, Murray AT, Agadjanian V. A geographical perspective on access to sexual and reproductive health care for women in rural Africa. Soc Sci Med. 2013; 1(96): 60-8. http://dx.doi.org/10.1016/j.socscimed.2013.07.025

11. Khademi N, Reshadat S, Zanganeh A, Saeidi S, Ghasemi S, Zakiei A. Identifying HIV distribution pattern based on clustering test using GIS software, Kermanshah, Iran. HIV \& AIDS Review. 2016; 15(4): 147-52. http://dx.doi.org/10.1016/j.hivar.2016.11.003

12. Cinnamon J, Schuurman N, Crooks VA. A method to determine spatial access to specialized palliative care services using GIS. BMC Health Serv Res. 2008; 8(1): 140-51. http://dx.doi.org/10.1186/1472-6963-8-140

13. Dulin MF, Ludden TM, Tapp H, Smith HA, de Hernandez BU, Blackwell J, et al. Geographic information systems (GIS) demonstrating primary care needs for a transitioning Hispanic community. J Am Board Fam Med. 2010; 23(1): 109-20. http://dx.doi. org/10.3122/jabfm.2010.01.090136

14. Reshadat, S., Zangeneh, A., Saeidi, S., Teimouri, R. and Yigitcanlar, T., Measures of spatial accessibility to health centers: investigating urban and rural disparities in Kermanshah, Iran. J Public Health, 2018; In press: 1-11. https://doi.org/10.1007/s10389-0180966-9

15. Ebrahim Zadeh E, Ahdnzhad M, Ebrahim-Zadeh Smyn H, Shafiei Y. spatial organization and planning of Health Services by using (GIS); the case of Zanjan City . Res in Hum Geo. 2010; 11(73): 58-39.

16. Khakpoor BAPH, Ghanbari M. Location Health-Therapeutic Centers of Nourabad by Use Analytical Hierarchy Process in GIS. Health Inf Manag. 2014; 11(2): 1-20.

17. Reshadat S, Saedi S, Zangeneh A, Amooie M, Karbasi A. Equity in Access to Health Care Using Geographic Information System: a Kermanshah Case Study. J Mazandaran Univ. 2014; 115(24): 134-40. http://jmums.mazums.ac.ir/article-1-4100-en.html

18. Khademi N, Reshadat S, Zangeneh A, Saeidi S, Ghasemi S, Rajabi-Gilan N, et al. A comparative study of the spatial distribution of HIV prevalence in the metropolis of Kermanshah, Iran, in 1996-2014 using geographical information systems. HIV Med. 2017; 18(3): 220-4. http://dx.doi.org/10.1111/hiv.12416

19. Pour-Mohammadi M. Urban land use planning. Tehran: Samt; 2003.

20. Reshadat S, Saedi S, Zangeneh A, Ghasemi SR, Rajabi-Gilan N, Karbasi A, Bavandpoor E. Spatial accessibility of the population to urban health centres in Kermanshah, Islamic Republic of Iran: a geographic information systems analysis. EMHJ-Eastern Mediterranean Health Journal. 2015; 21(6): 389-95. http://www.who.int/iris/handle/10665/255109

21. Mavoa S, Witten K, McCreanor T, O'Sullivan D. GIS based destination accessibility via public transit and walking in Auckland, New Zealand. J Transp Geogr. 2012; 20(1): 15-22. http://dx.doi.org/10.1016/j.jtrangeo.2011.10.001

22. Higgs G. A literature review of the use of GIS-based measures of access to health care services. Health Serv Outcomes Res Methodol. 2004; 5(2): 119-39. http://dx.doi.org/10.1007/s10742-005-4304-7

23. Oh K, Jeong S. Assessing the spatial distribution of urban parks using GIS. Landsc Urban Plan. 2007; 82(1): 25-32. http://dx.doi. org/10.1016/j.landurbplan.2007.01.014

24. Mamdouhi AR, Lavi M. The development a descriptive model of spatial access to public treatment services hinterland floating two-step method (Case Study: municipalities of region 10). Res in Hum Geo. 2013; 44(4): 61-74.

25. Strobl C. PostGIS, In: Shekhar S, Xiong H, (eds) Encyclopedia of GIS. Boston, MA: Springer; 2008:891-8. http://dx.doi. org/10.1007/978-0-387-35973-1_1012

26. Shams M, Masoompour J, Saedi Sh, Shahbazi H. Assessment of Earthquake Disaster management worn tissues in Kermanshah Case Study: Faizabad neighborhood. Quarterly Environmental Based Territorial Planning Journal. 2011; 4(13): 41-66.

27. Taylor DM, Yeager VA, Ouimet C, Menachemi N. Using GIS for administrative decision-making in a local public health setting. Public Health Rep. 2012; 127(3): 347-53. http://dx.doi.org/10.1177/003335491212700316

28. Hare TS, Barcus HR. Geographical accessibility and Kentucky's heart-related hospital services. Appl Geogr. $2007 ; 2$ (3): 181-205. http://dx.doi.org/10.1016/j.apgeog.2007.07.004

29. Bagheri N, Benwell GL, Holt A. Measuring spatial accessibility to primary health care. 17th Annual Colloquium of the Spatial Information Research Centre, November 24-25, 2005, Dunedin, New Zealand.

30. Freeman HE, Blendon RJ, Aiken LH, Sudman S, Mullinix CF, Corey CR. Americans report on their access to health care. Health Aff. 1987; 6(1): 6-8. http://dx.doi.org/10.1377/hlthaff.6.1.6

31. Reshadat S, Zangeneh A, Saeidi S, Ghasemi SR, Rajabi -Gilan N, Abbasi S. Investigating the economic, social and cultural factors influencing total fertility rate in Kermanshah. J Mazandaran Univ. 2015; 25(127):108-12. http://jmums.mazums.ac.ir/article-1-5951en.html

32. Mosavi Daramrodi L, Shams M, Ghanbari N. The Analysis of Developmental opportunities in an old urban texture (Case Study: Down town Kermanshah). Environmental Based Territorial Planning (Amayesh). 2014; 7 (25):111-28. 
33. Redondo-Sendino Á, Guallar-Castillón P, Banegas JR, Rodríguez-Artalejo F. Gender differences in the utilization of health-care services among the older adult population of Spain. BMC Public Health. 2006; 6(1):155-64. http://dx.doi.org/10.1186/1471-2458-6155

34. Nemet GF, Bailey AJ. Distance and health care utilization among the rural elderly. Soc Sci Med. 2000; 50(9): 1197-208. http://dx. doi.org/10.1016/S0277-9536(99)00365-2

35. Reshadat S, Zangeneh A, Saeidi S, Izadi N, Ghasemi SR, Rajabi-Gilan N. A Feasibility Study of Implementing the Policies on Increasing Birth Rate with an Emphasis on Socio-economic Status: A Case Study of Kermanshah Metropolis, Western Iran. Soc Indic Res. 2018; In press: 1-8. https://doi.org/10.1007/s11205-017-1790-2

36. Cromley E, McLafferty S. GIS and public health. New York, NY: Guilford Press; 2002. 